\title{
DAYAH AND MEUNASAH IN ACEH: REFORM IN LOCAL CONTEXT
}

\author{
Moch. Khafidz Fuad Raya \\ Institut Agama Islam Darullughah Wadda'wah Pasuruan, Jawa Timur, Indonesia \\ hafidzraya@yahoo.co.id
}

\begin{abstract}
The history of Islamic education in the early 20th century led to various changes, especially the emergence of madrasas as an Islamic schooling system. Traditional Islamic educational institutions inevitably have to harmonise and open themselves to transformation, even though they initially experienced opposition. Using a qualitative approach with a narrative documentation method based on historical texts and observations in several Islamic educational institutions in Aceh, this article focuses on revealing the history of the dayah and meunasah as a traditional Acehnese Islamic educational institution that underwent some fundamental changes. The results found: First, the existence of the dayah is more long-term than the meunasah even though both forms of this institution are rooted in the same ideological principles with different patterns, seen from the early 20th century until implementing sharia law in Aceh after the Helsinki peace agreement, the dayah was still existed by maintaining its institutional form. Second, the emergence of madrasas as a formation of the government's political policy on the social conditions of the people that occurred has provided space for traditional Islamic educational institutions (such as the dayah) to open themselves to including general subjects, although this second result has led to struggles; Third, there is a contestation between dayah, Islamic schools, and madrasas, with public schools driven by traditionalist and modernist groups in maintaining their existence. The contest has opened the history of the dayah and meunasah into the form of public schools and madrasas in the future, both of which apply Islamic religious material, where public schools are superior to madrasas in terms of curriculum, educational programs, and human resources.
\end{abstract}

Keywords: Islamic education, dayah, meunasah, madrasa, school.

\section{INTRODUCTION}

The last few decades have seen a wave of interest in the study of Islamic education, especially about Islamic boarding schools (called pondok pesantren) in Indonesia by several Muslim scholars both from 
Indonesianists and Orientalists (H. Azra, 2018; Dhofier, 1980, 1994; Nilan, 2009; Pohl, 2006; Sauri, 2018). However, until now the study has focused on the general context, mostly studying pesantren in Java, especially the local context, which of course contributes to the variety of developments in pesantren in Indonesia. Very few scholars reveal the Islamic education system in Aceh that existed for centuries, which played an important role in the transmission of Islamic educational ideas in Indo-Malay relations since the mid-seventeenth century.

Currently, the number of pesantren in Indonesia is 26,974, and 82,355 madrasas spread from Aceh to Papua. Of these, 1,443,233 students (mukim) and 2,564,093 students (non-mukim) were recorded, making Indonesia one of the largest Islamic education systems in the world (A. Azra et al., 2010; Roslan Mohd Nor \& Malim, 2014). In some areas outside Java, such as in Aceh, 1,177 pesantren are ranging from elementary schools (ibtidaiyah) to secondary schools (tsanawiyah and aliyah). In Aceh, the term pesantren is referred to by various terms, there are Dayah, Rangkang, and Meunasah. Each of these terms has similarities and differences, all of which refer to the traditional pesantren system, even though there are pesantren in modern Aceh. In the twentieth century, the pesantren that still exist in Aceh are meunasah and dayah (Alfian, 1975; Barter, 2011; Rizal \& Iqbal, 2018; Roche, 2012, pp. 19002000).

Dayah is a typical Acehnese educational institution whose goal is to regenerate 'ulama' (Buto, 2016), whose emergence is thought to coincide with pesantren in Java. Derived from the word zawiyah corner of the mosque, which means the centre of the mystical life of Sufism adherents, such as the one in the Prophet's mosque during the time of the Prophet Muhammad. Teachers who teach at Dayah have high prestige and are more respectable than teachers who teach at other Islamic educational institutions (Ilyas, 2019). The Dayah teachers are members of a special 
community among Acehnese 'ulama' so that their religious knowledge is more qualified. On the way, the people of Aceh came to know the pesantren with the term meunasah. After the legendary dayah among the elderly in Aceh, there were many institutional changes accompanied by the times, so that meunasah was more popular among the people (Dhofier, 1990; Hasballah, 2020).

In terms of human resources, almost all the teachers who teach at the meunasah are male, while teungku inong (the term for female teachers) teaches Islam in their place of residence, not in the meunasah accommodation. To block religious education, the colonial government in the early 20th century (circa 1905) established several western-style schools to separate society from (secular) religion. The schools established by the Dutch, which differed from the education system in meunasah and dayah, had become the consumption of the elite of the Acehnese society, such as uleebalangs (tribal chiefs) and some indigenous people who worked in Dutch offices. Some Acehnese refuse to send their children to Dutch-made schools because they are afraid that their religion will be damaged and the invaders are like colonialists so that sentiment towards the Dutch is very strong for the Acehnese. People assume that if they study in Dutch schools, children will be influenced by infidel teachings that oppose all religious orders (Dhofier, 1980; Merry \& Milligan, 2009), especially among traditionalist Muslim groups. The blockade efforts did not stop there, the Dutch then implemented a teacher ordinance whose aim was to control religious subjects such as Arabic, Fiqh, Tawhid, and Islamic History. Even Kreisel in his findings mentions that the Dutch plan for the blockade was motivated by missionary missions (Kreisel et al., 2003).

During this period, a new initiative emerged by the people of Aceh, namely the establishment of a religious school called a madrasa in the 1910s (R. Hefner, 2008). Compared to the dayah and meunasah, 
madrasah has the characteristics of adopting a modern school system with a class assessment system, general and religious subjects. There are tables and chairs to learn, and a curriculum that is fixed. As in other areas, the existence of madrasas in Aceh at the beginning of the 20th century experienced a stream of reform brought about by modernists where modernist ideas were brought to Indonesia through kaum muda (Bowen, 1984; Salim, 2013). The kaum muda movement is a wave of "going home" scholars who study in Mecca. Later, it was showed that the movement had studied in Egypt in the 1930s, such as Mahmud Yunus (Abdullah, 2009). Some modernist figures support madrasas as a modern alternative to Islamic education, for example, Ali Hasjmy, former governor of West Sumatra from 1957 to 1964 . Rivals of the modernists, the traditionalists, are represented by the figure of Abuya Mudawaly, the founder of PERTI (Persatuan Islam Tarbiyah Islamiyah) which strengthened the dayah education system in Aceh.

After Indonesia's independence, religious schools, especially madrasas, were managed by the government through the Ministry of Religion to standardise and centralise the religious education system (Zuhdi, 2006). The post-conflict between the Indonesian government and the Free Aceh Movement (GAM) affected Islamic educational institutions. The tension escalated when several dayah teachers were killed and several schools were burned down between 2000-2001. Because of the conflict, the government then took curative steps by granting special autonomy status to Aceh as a special province. The application of Islamic law and special regional autonomy has influenced the social life of the community, including several policies for public schools and religious schools in Aceh (Shah \& Lopes Cardozo, 2014).

This article attempts to examine the background behind the reform of the dayah and meunasah since the early 20th century in the locality's context of Aceh. Overall, this article provides a new understanding that 
Islamic education in Indonesia is not homogeneous. Using case studies extracted with some interviews, related literature, and personal observations provides another pattern of Islamic education in Aceh that is unique.

\section{METHOD}

This article attempts to examine how the reformation of the dayah and meunasah in locality in Aceh since the early 20th century has undergone a change in form but has kept its traditional principles and ideology. This article also reveals how the reformation of the dayah and meunasah before and after implementing Islamic sharia law in Aceh after the armed conflict emerged where there was a contestation between traditionalist and modernist groups. With the focus and purpose of this research, this article uses a qualitative approach to documentation methods from various historical texts and observations at several Islamic educational institutions in Aceh, where this method is used to reveal historical aspects and conditions of the dayah and meunasah in the early 20th century until now.

\section{FINDINGS AND DISCUSSION}

\section{History and Development of Dayah and Meunasah in Aceh}

If observed directly, actually all villages in Aceh have at least one meunasah as a forum for the community to receive religious teachings. In addition, the function of the meunasah is as a place of accommodation for adult men who want to study religion, a kind of pesantren in Java. Adult men, called gampong (Hurgronje, 1906; Sufri et al., 2020), stay at the meunasah just to interact or learn Islamic religious knowledge (Kloos, 2014; Widianti, 2006). At the meunasah, children and adults learn the Qur'ān and Hadīth and other books (such as masā'il al-muhtadi) through Islamic textbooks in Malay in Arabic script. Learning Islam during the 
colonial period was difficult. The community was restricted and even prohibited by the colonial government from studying religion in the meunasah. According to Hefner's findings, the meunasah is the only Islamic educational institution in Aceh for the indigenous population (R. W. Hefner, 2008). However, at present, the function of the meunasah culture among the people of Aceh has faded and has even reached extinction because of globalisation and the modernisation of education.

In order, those who have completed their basic religious education at the meunasah are required to continue to dayah to gain more religious knowledge than the basics. There are three grade levels in the zawiyah or dayah: (1) bilek for novice students, (2) rangkang for middle-class students, (3) and balee for students who are already proficient in Islamic religious knowledge (Marzuki, 2011); and each 'ulama' also differs in class, for example tengku bilek, tengku rangkang, and tengku balee (Burhanudin, 2014). History mentions that dayah became a target for the Dutch colonialists to destroy. Before the fall of the Aceh Darussalam kingdom in 1874, there had been several burnings of the dayah and some of its 'ulama' were killed, but after that the dayah returned to lead as an institution that strongly opposed colonialism in Aceh by many 'ulama' and students who were involved in a battle with the Dutch (Morris, 2021). Even Haji Hasan Mustapa's involvement in obtaining information about Teuku Umar's cooperation with the invaders was based on information from Haji Hasan Mustapa's friend Snouck Hurgronje who lived in Batavia from 1873-1912 (Rohmana, 2021).

Dayah's glory shone again after Abuya Mudawaly founded Dayah Darussalamin Labuhan Haji in 1936 as initiation to strengthen the dayah which had been destroyed by the Dutch. After that, Abuya Mudawaly formed a dayah network called Persatuan Islam Tarbiyah Islamiyah or PERTI. With the light of the dayah again, the resistance to including general subjects into the dayah curriculum has become even more 
intense, although in the 1920s pesantren in Java (such as Tebuireng) had opened up to include general subjects in the pesantren curriculum (A. Azra et al., 2010, p. 75), because several pesantren in Java flocked to establish madrasas as an alternative education system to provide opportunities for modern curricula to enter pesantren (Lukens-Bull, 2010). Dayah's resistance is not only criticism of the curriculum but also claims that those who study in modern schools are kafir. Initially, the claim was only on Dutch schools but eventually expanded to schools that incorporated a modern curriculum system into their schools. This wave of sentiment in Aceh occurred around the 1970s to 1990s. However, in 2008, based on the consideration of the Dayah Education and Development Agency which was formed by the Aceh government, the dayah opened themselves up to adopt modern education by including general subjects but still maintaining their traditional identity, namely teaching the yellow book and traditional tarekat rituals typical of the dayah.

The transformation of Islamic education has also affected Aceh, where the dayah as a traditional institution must "give up" for its existence. The insertion of general subjects and modern systems into traditional schools, such as dayah is an attempt to respond to modernity (Jackson \& Parker, 2008; Lukens-Bull, 2019). Now, when you look at the dayah curriculum, you will be treated to general subjects such as English, biology, economics, computers, and geography.

\section{Madrasah contest in Aceh}

Madrasah is an Islamic educational institution in the archipelago known since the twentieth century, which was founded by religious organisations and or several influential religious figures. After Indonesia's independence, the government took over the madrasas with a centralised policy, but the management of each madrasa was autonomous 
so that many madrasas emerged in Indonesia with two types of status: private madrasas (madrasah swasta) and public madrasas (madrasah negeri). Unlike in Indonesia, public madrasas in Morocco are not included in the category of Islamic educational institutions (Boyle \& Boukamhi, 2018).

In some places in Aceh, madrasas have existed since the late 1920s. Among them on the west coast of Aceh there is the Tawalib Sumatera Madrasah which is affiliated with the West Sumatera Madrasah and the Labuhan Haji Madrasah in Meulaboh (Saerozi, 2014). While on the north coast of Aceh there is Madrasah Diniyah Islamiyah Sigli, then two madrasas such as Jamiah al-sihlah wa al-Irsyad al-Arabiyah in Lhokseumawe and madrasah Ahlussunah wal Jama'ah Tgk. A. Wahab Seulimeum was founded by Arab merchants named Sheikh al-Kalali and Sayyid Husin Shihab. Other figures such as Tgk. Sheikh Ibrahim Lamnga founded Madrasah Najdiyah (1926) and Madrasah Jamiah Diniyah alMontasiah (1930) with a tribal chief (uleebalang) named Montasik T. Main. In 1940, Teuku Muhammad Daud Panglima Polem, a XXII sagi mukim commander, founded a madrasa named Ma'had Imanil Mukhlis (Witkam, 2019). Meanwhile, on the north coast of Aceh, there are 3 figures, namely Teuku Muhd Daud, Teuku Meunasah Meutter and Teuku Syekh Abd. Hamid who founded Madrasah al-Muslim Matang Glumpang Dua (1929) and Madrasah Jamiatuddiniah Pidie (1930) (Buto \& Hafifuddin, 2020; Sufi, 1998; Sulaiman, 1985).

The subjects taught at the madrasas above are not limited to books based on Syafi'i madhhab such as the salaf pesantren in Java and dayah in Aceh, but the students are provided with general lessons such as English, IPA (Natural Sciences), IPS (Social Sciences), they are also given additional-curricular activities such as scouts and organisational training. In the madrasas above, teachers and students wear pants, long-sleeved uniforms, and ties like the students at Pondok Pesantren Gontor 
Ponorogo, East Java. They also call their teachers "ustadz" rather than "teungku" as in dayah, so that their activities are also modern in style, both in socialising and about their reading books. In the Kutaraja area, several schools rejected the traditional religious rituals taught in the dayah, so this action led to a confrontation between traditionalists and modernists (Srimulyani, 2016).

The contestation of madrasas as modern Islamic educational institutions sparked fierce events in the Muslim world in Southeast Asia, as modernist groups promoted the ideas of modernity through textbooks and journalism. They (modernists) claim that the traditionalist group is incompetent in managing Islamic educational institutions that have changed and been blown away by the current wave of modernity, while they (traditionalists) remain in their stance on "taqlid" on the understanding of centuries-old textuality that are no longer in the times than they are an independent search for understanding (ijtihad), even modernist groups consider traditionalist groups are "haram" to carry out ijtihad (R. W. Hefner, 2008). Madrasahs in Aceh reached their peak of fame when the PUSA (United People of All Aceh) was founded in 1939, which sought to revitalise madrasas in Aceh so that their existence would be stronger (Aspinall, 2020). Besides PUSA, there is a Muhammadiyah modernist group in Aceh that also promotes modernity in society. However, unlike PUSA, which has a lot of community support, its mission and ideology are deeply rooted.

If we reflect further, the contestation between traditionalists and modernist movements that carry both types of Islamic educational institutions (the traditionalist dayah and the modernist madrasa) is a religious-political event to gain their respective territories. The traditionalist group is symbolised by the charismatic figure Abuya Mudawaly and the modernist group is symbolised by the progressive figure of Abu Daud Beureueueh. There are indications that this modernist 
movement brought the seeds of rebellion to the government. Sure enough, PUSA was proven to have joined the DI/TII movement against President Soekarno, who he considered a "taghut". This action has implications for not ratifying madrasah teachers to receive salaries paid by the government as in government-owned public schools because madrasas are not state-owned schools. At PUSA's urging, the proposal was later approved on the condition that the madrasa became a "stateowned school" (Inayatillah, 2015). When a madrasah becomes a state school, madrasa teachers are paid the same as other schools (such as SRI, SGI, SMI, and SMIA). The government also changed the form of Islamicbased schools into madrasas, but madrasas in this context differ from the madrasas formed by PUSA.

During the Order Baru era, madrasas were "second-class" rather than public schools. This was seen when the reputation of the people who sent their children to madrasas became bad. Until the 1990s, the condition of the buildings and learning facilities in madrasas was poor, supported by many students but the lack of teachers with adequate skills, such as teachers in public schools. Although the government "me-negerikan" madrasas in 1974 through a Joint Decree of Three Ministers (Minister of Religion, Minister of Education, and Minister of Domestic Affairs), this did not have a beneficial effect on madrasas. This decision has a significant impact on the content of the curriculum structure, which must reduce the portion of religious subjects so that the composition is $70 \%$ general subjects and 30\% religious subjects. With this change, the quality of madrasa graduates from public schools is no different, although the government claims that it aims to align madrasah with state schools so that students can transfer to public schools or continue to higher education. This problem adds to the long series of gaps between the two education systems. 
Efforts to "equalise" madrasas with public schools on the one hand make madrasas lose their "religious" aspects as madrasa identities this equalisation has a good impact on parents who want to continue their children's education to a higher level or look for work without having to get a job. Additional certificates to support children's abilities. So that initially madrasas were educational institutions whose emphasis was on Islam, but nowadays it does not differ from public schools, even though madrasas remain under the umbrella of the Ministry of Religion. It turns out that many policies and rules of the education system are under the control of the Ministry of Education and Culture so that there is an impression that madrasas are adopted children who are entrusted to orphanages. At this stage, the dayah that used to exist with the material identity of the Islamic religion is now transformed into a traditional modern school.

\section{"Educating" Schools or "Schooling" Madrasas?}

As an effort by the government to resolve the armed conflict between the Indonesian government and GAM (Free Aceh Movement), a decentralisation policy was implemented in Aceh with the signing of the peace agreement in the Helsinki Agreement in 2005 (Lee, 2020; Morfit, 2007). Regional autonomy has been granted in Aceh to specifically apply sharia law in the national system (Afrianty, 2018). his sharia law policy also affects the realm of education as stated in Law No. 44 of 1999 clause 8, Aceh applies the concept of Islamic education. Then there is the regional Qanun through Perda (Regional Regulation) Number 6 of 2000 which states the inclusion of Islamic religious subjects in public schools so that there are hours devoted to subjects with an additional six to eight hours per week.

Several articles in some laws and regulations specifically strengthen the importance of Islamic religious subjects such as Regional Regulation Number 5 of 2008 concerning Islamic Religious Education, which 
reproduces religious material. The regional regulation was passed because it saw that there was no difference between religious material in madrasas and religious material in public schools from a curriculum point of view, for example, Aqidah (Islamic theology), Akhlak (Islamic ethics and morals), Fiqh (Islamic law), Qur'an Hadith, Tarikh Islam (Islamic history), and Arabic. Until now these subjects are taught in madrasas and schools. Teachers who teach Islamic religious materials have the same qualifications and skills even though in public schools some Islamic religion teachers are civil servants (PNS) while some religion teachers in madrasas are more still private. Some public schools in Aceh have even implemented an integrated school model, such as Fajar Harapan High School, which is the best high school in Aceh. Besides teaching Islamic religious material taught in madrasas, Fajar Harapan High School also teaches the yellow book in its curricula such as Matn taqrib, Akhlāq li al-banin and Masāil al-muhtadī which are included in extracurricular activities, even the books of Matn taqrib and Akhlāq li albanin are integrated with the six Islamic religious subjects that are rarely used by madrasas. Because it is integrated, Fajar Harapan High School implements a dormitory system like a boarding school with communication and interaction of students while in school accommodation using Arabic and English (bilingual). The Design of Standardised Schools seems to be an inspiration for public schools to outperform madrasas by promoting Islamic religious material. Various breakthroughs and educational programs are designed in such a way as to resemble a dayah, such as the khitobah (public sermon) program.

If we observe further, public schools in Aceh are more Islamic than madrasas because public schools are projected to be the same schools as madrasas. Public schools have extracurricular activities such as book reviews, general recitation, istighosah, dhikr assemblies, and other programs. The primary aim is actually to blur the distinction between 
madrasas which are prepared by the state to become Islamic schools and public schools known as schools that separate religious subject from general subject (secular). Although in the end, this can also eliminate the true identity of the madrasa as an Islamic school. Besides teaching scriptures, urban public schools are also introduced to students with writing skills in Malay script, a congregational prayer program (because of an integrated system), and during Ramadan the material in school is converted into intensive religious learning. There is another interesting thing, with implementing Islamic law in Aceh, all public schools must wear Muslim clothes, especially for students who are required to wear a headscarf and cover their genitals. In the past, those who were required to wear headscarves were only dayah and madrasah students.

The orientation of Islamic education in Aceh is institutionally changing. In the past, madrasas were projected to be on par with the general school system, but recently, public schools have been aggressively making many breakthroughs that can outperform the madrasa program. "Educating" schools or "Schooling" madrasas, are two different things but with the same goal of blurring the dichotomy between public schools and madrasas. Implementing Islamic law in Aceh is also one factor for schools to implement programs as implemented in madrasas, even exceeding the implementation of the Integrated Islamic School. Most public schools have changed their curricula to include more Islamic religious material, even some schools teach the yellow book as an extracurricular program and integrate it into Islamic religious education subjects which madrasas have not done so far.

\section{CONCLUSION}

The transformation and development of Islamic education in Indonesia, especially in Java, has a similar model. In the early days of Islam, traditional learning was developed to spread Islam throughout 
society as a medium of da'wah. Second, the idea of renewal emerged from reformers who wanted modernity as a solution for Islamic education to get out of the traditional puddle. However, if we look closely and indepth, the form of change is different considering the different political and social backgrounds of the people. In Aceh, for example, although the model is similar, the form and conditions differ from the reform of Islamic education in Java. The contestation between modernity and traditional has filled the sheets of reforming Islamic education in Aceh along with the political and social changes of the Acehnese people, especially the armed conflict and implementing sharia law in Aceh, causing the effect of adopting a local context for change and transformation of Islamic education in Aceh.

This article finds that the existence of the dayah is longer-term than the meunasah even though these two forms of institutions are rooted in the same ideological principles although, with different patterns, seen from the early 20th century until implementing sharia law in Aceh after the Helsinki peace agreement, the dayah still existed maintain its institutional form. The emergence of madrasas as a formation of the government's political policy on the social conditions of the people that occurred has provided space for traditional Islamic educational institutions (such as dayah) to open themselves to including general subjects. This causes the opening of a "gaping space" for the contestation struggle between dayah, Islamic schools, and madrasas, with public schools driven by traditionalist and modernist groups in maintaining the existence of these Islamic educational institutions. Even though in the end what happened, public schools were superior to madrasas where there were more Islamic religious materials and programs, so there was a term that emerged in the community as "school madrasas" and or "schooling madrasas". 


\section{REFERENCES}

Abdullah, T. (2009). Schools and Politics: The Kaum Muda Movement in West Sumatra (1927-1933). Equinox Publishing.

Afrianty, D. (2018). Women's responses to the implementation of Islamic law in Aceh. In Routledge Handbook of Contemporary Indonesia. Routledge.

Alfian. (1975). The Ulama in Acehnese Society: A Preliminary Observation. Southeast Asian Journal of Social Science, 3(1), 27-41.

Aspinall, E. (2020). Islam and Nation. In Islam and Nation. Stanford University Press.

https://www.degruyter.com/document/doi/10.1515/9780804776271 /html

Azra, A., Afrianty, D., \& Hefner, R. W. (2010). Chapter 8. Pesantren and Madrasa: Muslim Schools and National Ideals in Indonesia. In Schooling Islam (pp. 172-198). Princeton University Press. https://www.degruyter.com/document/doi/10.1515/9781400837458 $.172 / \mathrm{html}$

Azra, H. (2018). Islamic Education in Indonesia. International Handbooks of Religion and Education, 7(1), 763-780.

Barter, S. J. (2011). Ulama, the state, \& war: Community Islamic leaders in the Aceh conflict. Contemporary Islam, 5(1), 19-36. https://doi.org/10.1007/s11562-010-0141-8

Bowen, J. R. (1984). Death and the History of Islam in Highland Aceh. Indonesia, 38, 21-38. https://doi.org/10.2307/3350843

Boyle, H. N., \& Boukamhi, A. (2018). Islamic Education in Morocco. In H. Daun \& R. Arjmand (Eds.), Handbook of Islamic Education (pp. 625-636). Springer International Publishing. https://doi.org/10.1007/978-3-31964683-1_37

Burhanudin, J. (2014). History, Authority, and Power: A Case of Religious Violence in Aceh. Journal of Indonesian Islam, 8(1), 112-138. https://doi.org/10.15642/JIIS.2014.8.1.112-138 
Buto, Z. A. (2016). Modernisation of dayah in aceh. Islamic Quarterly, 60(3), 305-320.

Buto, Z. A., \& Hafifuddin, H. (2020). Dayah Santri in Aceh: Early History and Recently Development. Journal of Contemporary Islam and Muslim Societies, 4(1), 132-165. https://doi.org/10.30821/jcims.v4i1.8090

Dhofier, Z. (1980). The Pesantren Tradition: A Study of the Role of the Kyai in the Maintenance of the Traditional Ideology of Islam in Java. https://doi.org/10.25911/5d74e363a6ded

Dhofier, Z. (1990). Traditional islamic education in the malav archipelago: Its contribution to the integration of the malay world. Indonesia Circle. School of Oriental \& African Studies. Newsletter, 19(53), 19-34. https://doi.org/10.1080/03062849008729746

Dhofier, Z. (1994). The Role of Pesantren in the Development of Primary Education in Indonesia. Studia Islamika, 1(2), 47-67. https://doi.org/10.15408/sdi.v1i2.857

Hasballah, M. (2020). Meunasah: Lembaga Pendidikan Islam Tradisional Aceh. At-Tafkir, $13(2)$ 173-186. https://doi.org/10.32505/at.v13i2.1848

Hefner, R. (2008). 1. Introduction: The Politics and Cultures of Islamic Education in Southeast Asia. In Making Modern Muslims (pp. 1-54). University of Hawaii Press. https://www.degruyter.com/document/doi/10.1515/9780824863463 $-003 / \mathrm{html}$

Hefner, R. W. (2008). Making Modern Muslims: The Politics of Islamic Education in Southeast Asia. University of Hawaii Press.

Hurgronje, C. S. (1906). The Atjehnese. Leiden: EJ Brill.

Ilyas, M. (2019). Leadership transformation; study of islamic boarding school (DAYAH) in Aceh Province Of Indonesia. Journal of Entrepreneurship Education, 22(2). https://api.elsevier.com/content/abstract/scopus_id/85067116762 
Inayatillah, I. (2015). Responses of Madrasah toward Social Changes in Aceh Society. Proceeding of The International Seminar and Conference on Global Issues, $\quad 1(1), \quad$ Article 1. https://publikasiilmiah.unwahas.ac.id/index.php/ISC/article/view/12 72

Jackson, E., \& Parker, L. (2008). 'Enriched with Knowledge': Modernisation, Islamisation and the Future of Islamic Education in Indonesia. RIMA: Review of Indonesian and Malaysian Affairs. https://search.informit.org/doi/abs/10.3316/INFORMIT.1812925313 65317

Kloos, D. (2014). In the Name of Syariah? Vigilante Violence, Territoriality, and Moral Authority in Aceh, Indonesia. Indonesia, 98, 59-90. https://doi.org/10.5728/indonesia.98.0059

Kreisel, W., Weber, R., \& Faust, H. (2003). Colonial Interventions on the Cultural Landscape of Central Sulawesi by 'Ethical Policy': The Impact of the Dutch Rule in Palu and Kulawi Valley, 1905-1942. Asian Journal of Social Science, 31(3), 398-434. https://doi.org/10.1163/156853103322895324

Lee, T. (2020). Political orders and peace-building: Ending the Aceh conflict. Conflict, Security \& Development, 20(1), 115-139. https://doi.org/10.1080/14678802.2019.1705071

Lukens-Bull, R. (2010). Madrasa by Any Other Name: Pondok, Pesantren, and Islamic Schools in Indonesia and Larger Southeast Asian Region. JOURNAL OF INDONESIAN ISLAM, 4(1), 1-21-21. https://doi.org/10.15642/JIIS.2010.4.1.1-21

Lukens-Bull, R. (2019). Pesantren, Madrasa and the Future of Islamic Education in Indonesia. Kawalu: Journal of Local Culture, 6(1), 29-58. https://doi.org/10.32678/kawalu.v6i1.2044 
Marzuki, M. (2011). Sejarah dan Perubahan Pesantren di Aceh. Millah: Jurnal Studi Agama, 11(1), 221-233. https://doi.org/10.20885/millah.vol11.iss1.art11

Merry, M. S., \& Milligan, J. A. (2009). Complexities of Belonging in Democratic and Democratizing Societies: Islamic Identity, Ethnicity and Citizenship in the Netherlands and Aceh. Journal of Muslim Minority Affairs, 29(3), 311-323. https://doi.org/10.1080/13602000903166572

Morfit, M. (2007). The Road To Helsinki: The Aceh Agreement and Indonesia's Democratic Development. International Negotiation, 12(1), 111-143. https://doi.org/10.1163/138234007X191939

Morris, E. (2021). Aceh: Social Revolution and the Islamic Vision. In Regional Dynamics of the Indonesian Revolution (pp. 83-110). University of Hawaii

Press. https://www.degruyter.com/document/doi/10.1515/9780824887391 $-006 / \mathrm{html}$

Nilan, P. (2009). The 'Spirit of Education' in Indonesian Pesantren. British Journal of Sociology of Education, 30(2), 219-232. https://doi.org/10.1080/01425690802700321

Pohl, F. (2006). Islamic Education and Civil Society: Reflections on the Pesantren Tradition in Contemporary Indonesia. Comparative Education Review, 50(3), 389-409. https://doi.org/10.1086/503882

Rizal, M., \& Iqbal, M. (2018). Dayah and Meunasah: Abu Teupin Raya is the reformer of Islamic Education in Aceh. Jurnal Pendidikan Islam, 7(1), 185-207. https://doi.org/10.14421/jpi.2018.71.185-207

Roche, S. (2012). Dayah, the Traditional Islamic Education System of Aceh 1900-2000. Media Syari'ah : Wahana Kajian Hukum Islam Dan Pranata Sosial, 14(2), 239-250. https://doi.org/10.22373/jms.v14i2.1879

Rohmana, J. A. (2021). Colonial informants and the Acehnese-Dutch war. Indonesia and the Malay World, 49(143), 63-81. https://doi.org/10.1080/13639811.2021.1855022 
Roslan Mohd Nor, M., \& Malim, M. (2014). Revisiting Islamic Education: The Case of Indonesia. Journal for Multicultural Education, 8(4), 261-276. https://doi.org/10.1108/JME-05-2014-0019

Saerozi, M. (2014). Model of strategies in developing Islamic thought through curriculum: A study of Sumatra Thawalib. Indonesian Journal of Islam and Muslim Societies, 4(2), 233-255. https://doi.org/10.18326/ijims.v4i2.233-255

Salim, D. P. (2013). Islam, Politics and Identity in West Sumatra. Journal of Indonesian $\quad$ Islam, $\quad 7(1), \quad 96-118$. https://doi.org/10.15642/JIIS.2013.7.1.96-118

Sauri, S. (2018). A critique of local wisdom values in Indonesia's pesantren. Pertanika Journal of Social Sciences and Humanities, 26(Query date: 2021-06-21 06:00:10), 37-50.

Shah, R., \& Lopes Cardozo, M. (2014). Education and social change in postconflict and post-disaster Aceh, Indonesia. International Journal of Educational Development, 38, 2-12. https://doi.org/10.1016/j.ijedudev.2014.06.005

Srimulyani, E. (2016). Teungku Inong Dayah: Female religious leaders in contemporary Aceh. Islam and the Limits of the State: Reconfigurations of Practice, Community and Authority in Contemporary Aceh, Query date: 2021-06-22 04:32:47, 141-165. https://doi.org/10.1163/9789004304864_007

Sufi, R. (1998). Gerakan nasionalisme di Aceh, 1900-1942. Departemen Pendidikan dan Kebudayaan, Balai Kajian Sejarah dan Nilai Tradisional Banda Aceh.

Sufri, S., Dwirahmadi, F., Phung, D., \& Rutherford, S. (2020). Enhancing community engagement in disaster early warning system in Aceh, Indonesia: Opportunities and challenges. Natural Hazards, 103(3), 2691-2709. https://doi.org/10.1007/s11069-020-04098-2 
Sulaiman, M. I. (1985). Islam et propagande anti-néerlandaise: Abdullah Arief et le Seumangat Atjeh (1945-1946). Archipel, 30(1), 207-217. https://doi.org/10.3406/arch.1985.2254

Widianti, E. T. R. (2006). The Ulama in Aceh in Time of Conflict, Tsunami and Peace Process: An Ethnographic Approach [Ohio University]. https://etd.ohiolink.edu/apexprod/rws_olink/r/1501/10?clear=10\&p 10_accession_num=ohiou1150410650

Witkam, J. J. (2019). Teuku Panglima Polem's Purse: Manuscripts as War Booty in Colonial Times. Journal of Islamic Manuscripts, 10(1), 84-104. https://doi.org/10.1163/1878464X-01001006

Zuhdi, M. (2006). Modernization of Indonesian Islamic Schools' Curricula, 1945-2003. International Journal of Inclusive Education, 10(4-5), 415427. https://doi.org/10.1080/13603110500430765 